industry of the European Commission.

In contrast, Environmental Monitoring and Assessment (EMA) has both well defined aims and named editors. "Environmental monitoring" can mean many things, but the declared objectives restrict consideration to pollutants, with emphasis on scientific principles in the design of monitoring systems, their imple-

\section{ENVIRONMENTAL MONITORING AND ASSESSMENT}

mentation and the consequent assessment of risk to man and the environment.

It is often argued that biological effects are difficult to detect in the field, and that measurements of rates of pollutant release and of degree of environmental contamination can be more meaningful than biological measurements. There are obvious attractions in such an approach, but given that field exposures usually fluctuate, and that we lack information on exposure-effect relationships for fluctuating exposures, this is a big assumption to make. There is the added difficulty, for species other than our own and cultivated and domesticated species, that we are concerned with the effect on populations, not on individuals. One might hope, then, that this journal would give due prominence to consequences.

However, of 20 papers, only three include a significant discussion of biological effects. Of the rest, several take a rather theoretical approach to problems of monitoring: these often contain sensible suggestions, such as the need for clear objectives, and for close cooperation between all members of a survey team, but such ideas are not new.

In brief, it is difficult to evaluate the ideas or work described in many of the papers because there is no evidence on the effectiveness or otherwise with which biological effects are indicated. One paper exemplifies this preoccupation with methods rather than results: 0.5 ha plots of Montana grassland were fumigated with sulphur dioxide for up to five years, but although detailed studies were made of amounts, distribution and fluctuations of sulphur dioxide within and around the vegetation canopy, no observations appear to have been made on the plants' response, although the introduction does list many biological measures to be made with this exposure system. Without that information, the value of the system cannot be evaluated.

For EMA to become a more useful forum on monitoring, it needs to bring its lagging publication schedule up to date and place a greater emphasis on the biological aspects. Given that, it could become a worthwhile venture.

Frank Moriarty is a Principal Scientific Officer at Monks Wood Experimental Station, NERC Institute of Terrestrial Ecology, Huntingdon.

\title{
Topical tropical entomology from Africa
}

\section{R. F. Chapman}

Insect Science and Its Application. Editor Thomas R. Odhiambo. 4/yr. (Pergamon.) $£ 42.50, \$ 48.57$.

Nor content with founding the International Centre for Insect Physiology and Ecology (ICIPE) in Nairobi, Professor Odhiambo has now started the first international entomological journal to stem from black Africa.

The stated intention of Insect Science is to "transcend the traditional boundaries of entomology" by its multi-disciplinary approach. The first issue, devoted to papers given at an ICIPE workshop on the epidemiology of African trypanosomiasis, lives up to these aims. Subsequently the papers have lapsed into a more usual entomological mould, though still covering the field from ultrastructure and neurophysiology to ecology and control. Most of the papers, which are generally short descriptive communications, could find a home in various more specialized journals, but many general entomologists especially in the tropics will appreciate having a variety of topics collected together as they in Insect Science.

A significant contribution of the journal to date is in publishing papers presented at three workshops, two held at ICIPE on trypanosomiasis and sorghum shoot flies, and one at the University of Ibadan on identification services and taxonomic research centres in Africa. These have been sufficiently wide in scope to be of interest to a wider audience than just those concerned specifically with the topics reviewed.

Although the intention is for the journal to cover entomology in the tropics generally - a point which is not clear from the title - the bias has been very strongly African. This is not necessarily bad, for there is plenty of scope for African entomology. More worrying has been a tendency for Insect Science to be something of a house journal for ICIPE. This may have been necessary to get the journal off the ground, but clearly cannot go on if it is to achieve international stature and become a "must" for all those interested in African entomology. Professor Odhiambo will no doubt be aware of this problem and it is to be hoped that he has the international support to overcome it. Assuming that he does so, and

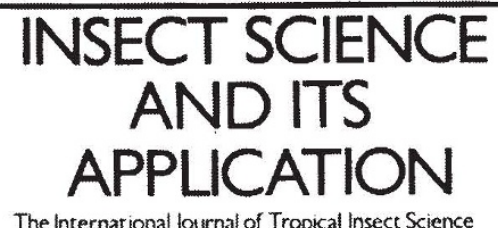

can maintain the standard, this journal will be a worthy addition to the entomological literature.

R.F. Chapman is an Assistant Director at the Centre for Overseas Pest Research, London.

\section{European niche}

\section{A. d'A. Bellairs}

Amphibia-Reptilia. Managing co-editors H. Hemmer and A. Dubois. 4/yr. (Akademische Verlagsgesellschaft, Wiesbaden, FRG.) DM 108.

THE appearance of a new journal of authoritative cast, a fit counterpart to some of the better North American productions, is an event of some note for European herpetology.

Amphibia-Reptilia is the journal of the Societas Europaea Herpetologica, founded in 1979. It is published in West Germany, with co-editors in Germany and France, and contains original papers of moderate length in English, French, German and Spanish, together with shorter

\section{Amphibia-Reptilia 18ji Publication of the Societas Europaea Herpetologica}

articles, news of its parent society, book reviews and obituaries. The main papers contain abstracts in English and often in another language also.

Well produced and well illustrated in an attractive format, the journal is a professional-looking publication. It deals with a wide variety of topics, including systematics (biochemical and otherwise), genetics, evolution, morphology from the ultrastructural to the gross level, physiology, ecology and behaviour. This catholic approach reflects the fact that herpetology is still more of a coherent discipline than the study of most of the other major groups of vertebrates.

This journal seems to occupy a definite niche in the zoological literature of Europe and is much to be welcomed; together with the British Journal of Herpetology in its new, improved form, it should stimulate progress in a subject which seems to be under-represented in many British university departments of zoology.

A.d'A. Bellairs is Emeritus Professor of Vertebrate Morphology in the University of London and Honorary Consulting Herpetologist to the Zoological Society of London. 